\title{
The Prospects for Indo-Pakistan Trade
}

\author{
Hafiz A. Pasha* and Muhammad Imran**
}

\begin{abstract}
This article analyzes the volume and pattern of India-Pakistan trade given the extent of trade complementarity between the two countries and, in the presence of a restricted positive list of imports from India, the tariff regime and nontariff barriers in the two countries. The study also assesses the impact on bilateral trade of granting most-favored nation status to India, the removal of some of the impediments to trade, and the implementation of the final phase of import tariff reduction under the South Asian Free Trade Agreement. Finally, the article highlights emerging opportunities and possible threats to the process of trade normalization between the two countries.
\end{abstract}

Keywords: exports, tariffs, non-tariff barriers, Pakistan, India.

JEL classification: F19.

\section{Introduction}

Trade between India and Pakistan has been fundamentally influenced by factors that are not purely economic. At the time of Partition in 1947, both economies were heavily interdependent, with the share of the Indian market in Pakistan's exports at close to one fourth, and over half of Pakistan's imports coming from India. Thereafter, bilateral trade has had a chequered history. Trade virtually ceased after the wars of 1965 and 1971.

Some positive steps have been made since 1995, when India announced its decision to grant most favored nation (MFN) status to Pakistan, and the latter established a positive list with respect to imports from India. The signing of the South Asian Free Trade Agreement (SAFTA) in 2004 was a major step forward in the eventual establishment of a customs union in the region. Recently, Pakistan has announced its potentially landmark decision to grant MFN status to India by the end of 2012. In the interim period, a restricted positive list has transitioned to a negative list, which opens up a large percentage of tariff lines for imports from India.

\footnotetext{
* Dean, School of Liberal Arts and Social Sciences, Beaconhouse National University, Lahore, Pakistan.

${ }^{* *}$ Research Associate, Institute of Public Policy, Beaconhouse National University, Lahore, Pakistan.
} 
Further, the two countries have agreed to simplify customs procedures and facilitate the process of goods certification. India has also announced that it welcomes investment by resident Pakistanis and companies.

Clearly, the environment for bilateral trade has greatly improved. This augurs well for future growth in trade between the two countries, who are making an effort to move away from the old view of "peace first, trade later" to "trade now, peace later." It is hoped that the expansion of trade will create stronger constituencies for peace in both countries.

Our objective is to explore the possibilities of Indo-Pakistan trade in the new environment. Section 1 of the article describes the current level and pattern of bilateral trade. Section 2 identifies some basic issues in the context of trade development between the two countries. Section 3 quantifies the degree of trade complementarity between the Indian and Pakistani economies. Section 4 describes the levels of import tariffs in the two countries and their potential impact on the volume of trade. Section 5 assesses the existing nontariff barriers (NTBs), especially with regard to each other, and identifies the particular restrictions that need to be removed for trade to flourish. Section 6 evaluates the prospects for IndoPakistan trade, following the India's granting of MFN status and Pakistan's reciprocal gestures in the form of relaxing certain NTBs.

\section{Trade Between India and Pakistan}

Both India and Pakistan have become substantially more open economies over the last four decades. The combined share of global imports and exports in India's GDP was less than 7 percent in 1970, but had risen to almost 32 percent by 2010. In Pakistan's case, the corresponding share has increased from 12 percent to 34 percent. Both countries have clearly realized the gains from global trade and how this can contribute to faster economic growth.

This increase in their degree of global openness is not, however, reflected in the trade between the two countries. As shown in Table 1, Pakistan's exports to India are of a small magnitude-only 1 percent (as compared to over one fourth at the time of Partition) of global exports and an insignificant portion of Indian imports. India's exports to Pakistan constitute only about 1 percent of its total exports, and about 5 percent of the latter's global imports (as compared to over half at the time of Partition). Clearly, any potential gains from trade have been sacrificed due to strained political relations. 
Table 1: Trade between Pakistan and India, 2000/01-2010/11

\begin{tabular}{lccc}
\hline \multicolumn{4}{c}{ Pakistani exports to India } \\
Year & $\begin{array}{c}\text { Exports } \\
\text { (USD million) }\end{array}$ & $\begin{array}{c}\text { Asercentage of } \\
\text { exports }\end{array}$ & $\begin{array}{c}\text { As percentage of } \\
\text { Indian imports }\end{array}$ \\
\hline $2000 / 01$ & 56 & 0.8 & 0.1 \\
$2006 / 07$ & 344 & 2.6 & 0.1 \\
$2009 / 10$ & 268 & 1.9 & 0.1 \\
$2010 / 11$ & 264 & 1.0 & 0.1 \\
\hline \multicolumn{4}{c}{ Indian exports to Pakistan } \\
Year & Exports & As percentage of & As percentage of \\
\hline $2000 / 01$ & (USD million) & exports & Pakistani imports \\
$2006 / 07$ & 238 & 0.4 & 2.7 \\
$2009 / 10$ & 1,236 & 1.1 & 5.1 \\
$2010 / 11$ & 1,226 & 0.9 & 4.2 \\
\hline
\end{tabular}

Source: State Bank of Pakistan.

Indian exports to Pakistan have been restricted by the latter's positive list. Only 27 percent of the tariff lines are open for imports from India (Table 2). The restriction is particularly severe in the case of product groups such as prepared foods, footwear and personal articles, textiles, ceramic and glass products, and vehicles and transport equipment. An estimated 77 percent of India's major exports (above USD 500 million) have been excluded from access to the Pakistani market. However, despite limited access, Indian exports have shown significant growth during the last decade, rising from USD 238 million in 2000/01 to USD 1,734 million in 2010/11. At the same time, while Pakistan enjoys MFN status with respect to India, its exports are not only very small, they have also shown a declining trend since 2006/07. 
Table 2: Positive list of items for import from India

\begin{tabular}{llrrr}
\hline $\begin{array}{l}\text { Section } \\
\text { of HC }\end{array}$ & \multicolumn{1}{c}{ Description } & $\begin{array}{c}\text { Total } \\
\text { tariff lines }\end{array}$ & $\begin{array}{c}\text { Lines in } \\
\text { positive } \\
\text { list }\end{array}$ & $\begin{array}{c}\text { Percentage } \\
\text { of tariff } \\
\text { lines }\end{array}$ \\
\hline I & Live animals, animal products & 248 & 33 & 13.3 \\
II & Vegetables and products & 311 & 157 & 50.5 \\
III & Animal, vegetable fats/oils & 53 & 2 & 3.8 \\
IV & Prepared foodstuffs & 228 & 11 & 4.8 \\
V & Mineral products & 195 & 74 & 37.9 \\
VI & Chemicals or allied industries & 1,149 & 574 & 50.0 \\
VII & Plastics and articles & 300 & 93 & 31.0 \\
VIII & Hides and skins, leather goods & 92 & 45 & 48.9 \\
IX & Wood and articles & 106 & 52 & 49.1 \\
X & Paper and paper board & 182 & 37 & 20.3 \\
XI & Textiles and articles & 929 & 104 & 11.2 \\
XII & Footwear and personal articles & 59 & 2 & 3.4 \\
XIII & Ceramic and glass products & 189 & 28 & 14.8 \\
XIV & Jewelry, etc. & 55 & 5 & 9.1 \\
XV & Metals and articles & 744 & 156 & 21.0 \\
XVI & Machinery & 1,193 & 353 & 29.6 \\
XVII & Vehicles and transport equipment & 245 & 15 & 6.1 \\
XVIII & Optical and precision instruments & 269 & 103 & 38.3 \\
XIX & Arms and ammunition & 52 & - & - \\
XX & Miscellaneous & 186 & 5 & 2.7 \\
XXI & Works of art & 72 & 1 & 1.4 \\
& Total & $\mathbf{6 , 8 5 7}$ & $\mathbf{1 , 8 7 0}$ & $\mathbf{2 7 . 3}$ \\
\hline
\end{tabular}

$\mathrm{HC}=$ Harmonized code.

Note: The percentage of tariff lines may not necessarily correspond to the percentage of imports.

Source: Pakistan, Ministry of Commerce (2012).

Tables 3 and 4 show the two countries' trade composition. As Table 3 indicates, two relatively large Indian exports to Pakistan were cotton (USD 372 million) and sugar (USD 69 million) in 2010/11-the year in which Pakistan was hit by devastating floods that badly affected standing crops. This is a classic example of how shortages can be met by a neighboring country, albeit at commercial terms. Other significant imports from India include soya bean oil cake, vegetables, chemicals, artificial staple fiber, and tea. It is interesting that the share of agricultural exports to 
Pakistan is almost 30 percent. This is in contrast to the pattern of trade at the time of Partition when India exported mostly manufactured consumer goods and imported agricultural items, such as cotton and wheat.

Table 3: Pakistan's major imports from India, 2010/11 and 2011/12

\begin{tabular}{llrr}
\hline & & \multicolumn{2}{c}{ July-May (USD million) } \\
HS code & \multicolumn{1}{c}{ Item description } & $\mathbf{2 0 1 0 / 1 1}$ & $\mathbf{2 0 1 1 / 1 2}$ \\
\hline & (> USD 50 million) & & \\
0702 & Tomatoes, fresh or chilled & 41 & 68 \\
0713 & Leguminous vegetables & 40 & 52 \\
1701 & Sugar & 69 & 0 \\
2304 & Soya bean oilcake & 122 & 202 \\
2902 & Cyclic hydrocarbons & 166 & 191 \\
5201 & Cotton & 372 & 75 \\
\hline & (> USD 20 million - $\leq 50$ million) & & \\
0902 & Tea & 26 & 36 \\
1209 & Seeds for fruits & 20 & 17 \\
2933 & Heterocyclic compounds & 25 & 29 \\
3204 & Synthetic organic coloring matter & 23 & 26 \\
3817 & Mixed alkyl benzenes & 17 & 24 \\
3901 & Polymers of ethylene & 3 & 20 \\
3902 & Polymers of propylene & 23 & 35 \\
5504 & Artificial staple fiber & 11 & 35 \\
7202 & Ferro alloys & 25 & 18 \\
7311 & Containers for compressed gas & 24 & 11 \\
Subtotal & & 982 & 839 \\
\hline Total & & $\mathbf{1 , 3 6 7}$ & $\mathbf{1 , 1 4 4}$ \\
Percentage of subtotal & 72 & 73 \\
\hline
\end{tabular}

Source: State Bank of Pakistan.

Pakistan's major exports to India are dates, cement, textiles, and certain chemicals. The export volumes are relatively small, as shown in Table 4. As opposed to its substantial imports of cotton from India in 2010/11, Pakistan exported cotton (USD 60 million) to India in 2011/12. There is also evidence of some intra-industry trade in sectors such as chemicals. A further promising sign is the emergence of some new exports to India, such as leather, woven cotton fabrics, and medical and surgical instruments, which are among Pakistan's major global exports. 
Table 4: Pakistan's major exports to India, 2010/11 and 2011/12

\begin{tabular}{|c|c|c|c|}
\hline \multirow[b]{2}{*}{ HS code } & \multirow[b]{2}{*}{ Item description } & \multicolumn{2}{|c|}{ July-May (USD million) } \\
\hline & & 2010/11 & 2011/12 \\
\hline & (> USD 10 million) & & \\
\hline 0804 & Dates & 44 & 48 \\
\hline 1006 & Rice & 13 & 1 \\
\hline 2520 & Gypsum & 1 & 11 \\
\hline 2523 & Cement & 39 & 33 \\
\hline 2707 & Oils from coal tar & 14 & 0 \\
\hline 2710 & Oils from petrol & 15 & 11 \\
\hline 2917 & Polycarboxylic acid & 12 & 16 \\
\hline 5201 & Cotton & 0 & 60 \\
\hline 5205 & Cotton yarn & 9 & 11 \\
\hline \multirow[t]{2}{*}{5209} & Woven cotton fabrics & 8 & 10 \\
\hline & (> USD 5 million $-\leq 10$ million) & & \\
\hline 2903 & Halogenated derivatives & 8 & 7 \\
\hline 4107 & Leather & 8 & 7 \\
\hline 5103 & Waste from wool & 7 & 4 \\
\hline 6305 & Sacks/bags of textile material & 5 & 5 \\
\hline 9018 & Medical and surgical instruments & 5 & 5 \\
\hline \multicolumn{2}{|l|}{ Subtotal } & 203 & 230 \\
\hline \multicolumn{2}{|l|}{ Total } & 268 & 311 \\
\hline \multicolumn{2}{|c|}{ Percentage of subtotal } & 76 & 74 \\
\hline
\end{tabular}

Source: State Bank of Pakistan.

Given its relatively large, growing volume of imports from India, and small, declining volume of exports to India, Pakistan has a relatively large trade deficit with respect to India, estimated at over USD 900 million in 2011/12. This has fueled arguments on the part of opponents of trade liberalization that further opening up will lead to a flood of Indian imports ${ }^{1}$ to the detriment of Pakistani industry. It must, however, be recognized that, to the extent that imports from India represent "trade diversion" at lower prices-especially with lower transport costs-from other sources, then while the trade balance with respect to India may deteriorate, the global balance of trade could improve.

1 The same concern was voiced when the Free Trade Agreement (FTA) was signed. However, although Chinese exports have reached USD 4.5 billion, many Pakistani industries have withstood the FTA well. 


\section{Key Issues}

The current level, pattern, and balance of trade between India and Pakistan raise a number of key issues. First, why have Pakistani exports performed poorly in India, despite the former's MFN status? There are a number of possible reasons for the low and declining volume of exports to India.

1. The trade complementarity between Pakistani exports and Indian imports may be low. In other words, Pakistan is not producing and exporting many of the goods that India imports globally. Therefore, there is low scope for diversion of Indian imports to Pakistan.

2. The regime of import tariffs and para-tariffs in India could be providing more effective protection to sectors in which Pakistan might potentially have a relative comparative advantage, for example, in some agricultural items and textiles.

3. India has a restrictive trade regime relative to other developing countries in terms of the range and intensity of NTBs. Additionally, it might be applying some of these barriers more rigorously to Pakistan, effectively raising costs for Pakistani exporters and precluding their access to the large Indian market.

As opposed to this, despite the limited positive list, Indian exports to Pakistan have done fairly well and shown rapid growth. This could be for the reasons below.

1. Given the two countries' relative level of development, especially in terms of the extent of diversification of the industrial base, there is a high level of trade complementarity between Indian exports and Pakistani imports. Consequently, following Pakistan's granting of MFN status to India, imports could rise substantially, especially due to diversion from more expensive sources.

2. Pakistan has a relatively more liberal trade regime. Generally, it has managed its protection policy for different economic activities primarily through import tariffs (and SROs); the presence of NTBs is limited. This has encouraged market penetration by Indian exporters.

Beyond the granting of MFN status to India, the final phase of trade liberalization in South Asia under SAFTA is expected to be completed by 31st December 2012. At this stage, items in all tariff lines (except those on each member country's sensitive list) will see import tariffs being reduced 
to 5 percent or less. ${ }^{2}$ The question is the extent to which this will further improve access for Indian exports to Pakistan. Is there even the possibility of some "trade creation" whereby Indian products begin to displace Pakistani products, and not just Pakistan's imports from other countries? Simultaneously, will lower Indian import tariffs provide greater opportunities to Pakistan exports?

It needs to be emphasized that, in the short- to medium-term, the prospects of raising Pakistani exports, both globally and specifically, to India, are limited by severe supply-side constraints. These include record levels of power load-shedding, and gas and water shortages, which have restricted the extent of capacity utilization. Simultaneously, private investment in Pakistan is at an all-time low.

In the subsequent sections, we try to find some answers to the questions raised above. First, we quantify the extent of trade complementarity between the two countries. This is followed by a comparison of their tariff regimes and incidence of NTBs. Based on these analyses, we assess the prospects for Indo-Pakistan post-31 $1^{\text {st }}$ December 2012, following the granting of MFN status to India and completion of the trade liberalization process under SAFTA.

\section{The Extent of Trade Complementarity}

We develop the following index of trade complementarity between two countries:

$$
T C I_{j k}=1-\frac{1}{2} \sum\left|m_{i k}-x_{i k}\right|, \quad 0 \leq T C I \leq 1
$$

where TCI $=$ trade complementarity index between countries $j$ and $k, m_{i k}=$ the share of the $i$ th commodity in the total imports of country $k$, and $x_{i j}=$ the share of the $i$ th commodity in the total exports of country $j$. The higher the magnitude of TCI, the greater will be the trade complementarity between the two countries.

The TCI has been estimated at the 4-digit HC level of India and Pakistan. The resulting magnitudes are as follows:

1. TCI between Indian exports and Pakistani imports $=0.420$

\footnotetext{
2 Pakistan has already notified vide SRO 558(1)/2004 the schedule of reduction of customs duties under SAFTA on different items by $31^{\text {st }}$ December 2012.
} 
2. TCI between Pakistani exports and Indian imports $=0.082$

Therefore, there is clear evidence that India is in a position to potentially export more items to Pakistan than the reverse. This is a major factor explaining the substantially larger volume of exports from India to Pakistan, even in the presence of the positive list. Table 5 lists significant Indian exports (above USD 250 million) that are also significant imports for Pakistan (above USD 100 million) for 2010/11. It shows that ten major Indian exports on Pakistan's positive list had a potential export value of USD 3.7 billion in the latter country. Actual exports in 2010/11 were worth USD 1.1 billion, implying that India's share in these exports was almost 30 percent. This share could increase further after the tariff reductions by Pakistan under SAFTA.

Following its transition to full MFN status and reduction in tariffs under SAFTA, a further market of over USD 11 billion potentially opens up for India in Pakistan, consisting primarily of the trade diversion of previously banned imports. If the market share in the old positive list rises to, say, 50 percent while that for new items reaches 30 percent in the medium term, Indian exports could rise to over USD 5 billion.

There are two other possibilities. The first is the diversion of informal trade - currently routed through the UAE, Singapore, and Iran or smuggled across the border-to formal channels after most items become importable from India. The volume of informal trade was estimated by the Sustainable Development Policy Institute (2007) at USD 500 million, and has by now probably increased to USD 1 billion. The second prospect is that of some "trade creation" with India, especially in products where tariffs are high (currently at 20 to 30 percent), which do not feature on the sensitive list, and which consequently experience a significant reduction in the tariff rate. Estimating the magnitude of trade creation requires detailed micro-studies of different sectors, which is the subject of further research. 
Table 5: Simultaneously significant Indian exports and Pakistani imports, 2010/11 (at 4-digit HC level)

\begin{tabular}{|c|c|c|c|c|c|}
\hline \multirow[b]{2}{*}{ No. } & \multirow[b]{2}{*}{ Code } & \multirow[b]{2}{*}{ Description } & \multicolumn{2}{|c|}{ Volume of global } & \multirow{2}{*}{$\begin{array}{l}\text { Pakistan's } \\
\text { imports } \\
\text { from India }\end{array}$} \\
\hline & & & $\begin{array}{l}\text { Indian } \\
\text { exports }\end{array}$ & $\begin{array}{c}\text { Pakistani } \\
\text { imports }\end{array}$ & \\
\hline \multicolumn{3}{|c|}{ Included in positive list* } & \multicolumn{3}{|c|}{ (USD million) } \\
\hline 1 & 0902 & Tea & 708 & 311 & 24 \\
\hline 2 & 1701 & Sugar & 1,196 & 691 & 335 \\
\hline 3 & 2304 & Soya bean oil cake & 2,057 & 142 & 51 \\
\hline 4 & 2902 & Cyclic hydrocarbons & 1,594 & 467 & 185 \\
\hline 5 & 2933 & Heterocyclic compounds & 600 & 113 & 11 \\
\hline 6 & 3204 & Synthetic coloring matter & 1,249 & 162 & 7 \\
\hline 7 & 3808 & Insecticides, etc. & 1,140 & 195 & 25 \\
\hline 8 & 3902 & Polymers of polypropylene & 771 & 435 & 17 \\
\hline 9 & 4011 & New rubber tyres & 1,029 & 144 & 42 \\
\hline 10 & 5201 & Cotton, not carded or combed & 2,866 & 1,031 & 406 \\
\hline \multicolumn{3}{|c|}{ Total } & 13,210 & 3,691 & 1,103 \\
\hline \multicolumn{6}{|c|}{ Not included in positive list } \\
\hline 11 & 2711 & Petroleum products & 41,076 & 8,261 & \\
\hline 12 & 3004 & Medicaments n.e.s. & 5,637 & 194 & \\
\hline 13 & 5402 & Synthetic filament yarn & 774 & 392 & \\
\hline 14 & 7208 & Flat rolled products of steel & 862 & 267 & \\
\hline 15 & 7210 & $"$ & 1,384 & 283 & \\
\hline 16 & 8471 & $\begin{array}{l}\text { Automatic data processing } \\
\text { machines }\end{array}$ & 285 & 103 & \\
\hline 17 & 8502 & Electrical generating sets & 342 & 289 & \\
\hline 18 & 8517 & Electric apparatus for telephony & 3,329 & 518 & \\
\hline 19 & 8703 & $\begin{array}{l}\text { Motor vehicles for transporting } \\
\text { persons }\end{array}$ & 4,211 & 477 & \\
\hline 20 & 8704 & Motor vehicles for transporting goods & 619 & 142 & \\
\hline 21 & 8708 & $\begin{array}{l}\text { Parts and accessories for motor } \\
\text { vehicles }\end{array}$ & 2,189 & 120 & \\
\hline 22 & 8711 & Motorcycles & 856 & 100 & \\
\hline 23 & 9018 & $\begin{array}{l}\text { Medical, surgical, and dental } \\
\text { instruments }\end{array}$ & 414 & 125 & \\
\hline Total & & & 61,978 & 11,271 & \\
\hline
\end{tabular}

* Note that not all items at the 8-digit level are part of the positive list. Items in italics are on Pakistan's sensitive list.

Sources: India, Ministry of Commerce and Industry (2012) (figures in last column); State Bank of Pakistan. 
Within the limited trade complementarity of Pakistani exports and Indian imports, we identify trade prospects following the relaxation of some NTBs (discussed in a subsequent section) and reduction in tariffs by India under SAFTA. Table 6 gives a list of potentially larger exports to India.

Table 6: Simultaneously significant* Pakistani exports and Indian imports*, 2010/11 (at 4-digit HC level)

\begin{tabular}{|c|c|c|c|c|c|}
\hline \multirow[b]{2}{*}{ No. } & \multirow[b]{2}{*}{ Code } & \multirow[b]{2}{*}{ Description } & \multicolumn{2}{|c|}{ Volume of global } & \multirow[b]{2}{*}{$\begin{array}{l}\text { Potential } \\
\text { diversion } \\
\text { to India** }\end{array}$} \\
\hline & & & $\begin{array}{c}\text { Pakistani } \\
\text { exports } \\
X_{i}\end{array}$ & $\begin{array}{c}\text { Indian } \\
\text { imports } \\
M_{i}\end{array}$ & \\
\hline & & & \multicolumn{3}{|c|}{ (USD million) } \\
\hline 1 & 0804 & Dates, figs, etc. & 100 & 180 & 100 \\
\hline 2 & 1001 & Wheat & 310 & 133 & 133 \\
\hline 3 & 2523 & Cement & 496 & 77 & 77 \\
\hline 4 & 3004 & Medicaments n.e.s. & 56 & 764 & 56 \\
\hline 5 & 3907 & Polyesters, primary & 265 & 1,024 & 265 \\
\hline 6 & 4102 & Leather & 79 & 60 & 60 \\
\hline 7 & 5007 & Woven fabrics of silk & 50 & 129 & 50 \\
\hline 8 & 5201 & Cotton, not carded or combed & 519 & 56 & 56 \\
\hline 9 & 5208 & Woven cotton fabrics & 519 & 159 & 159 \\
\hline 10 & 5209 & Woven cotton fabrics & 936 & 60 & 60 \\
\hline 11 & 5407 & Woven fabrics of synthetic yarn & 59 & 107 & 59 \\
\hline 12 & 6006 & Other knitted fabrics & 67 & 112 & 67 \\
\hline 13 & 6403 & Footwear & 72 & 56 & 56 \\
\hline 14 & 7113 & Articles of jewelry & 158 & 338 & 158 \\
\hline 15 & 9018 & Surgical instruments & 295 & 1,028 & 295 \\
\hline 16 & 9506 & Sports articles & 342 & 118 & 118 \\
\hline \multicolumn{3}{|c|}{ Total } & 4,323 & 4,401 & 1,769 \\
\hline
\end{tabular}

* At least USD 50 million each.

** Corresponding to $\mathrm{Min}[\mathrm{X} i, \mathrm{M} i]$ for the $i$ th product. Items in italics are on India's sensitive list.

Source: India, Ministry of Commerce and Industry (2012); State Bank of Pakistan.

Major Pakistani exports that could be further diverted to the Indian market (in view of lower transport costs) include dates, cotton, primary polyester, woven cotton and silk fabrics, jewelry, and sports articles. The quantum of total trade diversion is estimated at USD 1.8 billion (Table 6). If about 50 percent diversion takes place, exports could reach USD 900 million, as compared to USD 350 million currently. The prospect of such 
diversion-and possibly some trade creation-would improve if India were to relax some of its NTBs and if present impediments to trade were removed. Moreover, the competitive position of Pakistani exports to India would be enhanced if the SAFTA tariff reductions were implemented.

\section{Tariff Policies}

The low trade complementarity between Pakistani exports and India exists primarily because Pakistan does not a diversified exports base and its two product groups-agricultural items and textiles-account for 60 percent of its total exports. These are also major exports of India with a share of 17 percent. Of course, if free trade were to take place, a degree of specialization could develop, depending on relative comparative advantage. Pakistan could then find "niche" markets in India for a range of products from the two sectors.

The possibility of intra-industry trade has been largely precluded by the tariff policies pursued by India and support provided in the form of relatively large subsidies, especially to agriculture. Table 7 compares the level and pattern of import tariffs in the two countries, demonstrating that customs duties on agricultural products are significantly higher in India. For example, in cereals, and fruits and vegetables, India's average tariff on imports is 30-32 percent as compared to 18-19 percent in Pakistan. As opposed to this, Pakistan generally offers its domestic industry more protection.

Duty rates on textiles and clothing also appear to be lower in India than in Pakistan. This is the case for ad valorem duties, but India operates a dual tariff structure in these product groups with an ad valorem or specific duty, whichever is higher. Generally, the specific duties appear to be far higher and, in some cases, exceed 100 percent, especially on value-added textiles (see Table 8). These rates are even higher than India's tariff bindings with the World Trade Organization (WTO) in some cases. Pakistan, however, operates a normal ad valorem duty structure in clothing and textiles. 
Table 7: MFN-applied tariffs by product group in India and Pakistan*

\begin{tabular}{lrc}
\hline Product group & India & Pakistan \\
\hline Animal products & 33.1 & 14.6 \\
Dairy products & 33.7 & 30.0 \\
Fruit, vegetables, plants & 30.4 & 18.2 \\
Coffee, tea & 56.3 & 12.8 \\
Cereals and preparations & 32.2 & 18.8 \\
Oilseeds, fats, and oils & 18.3 & 8.8 \\
Sugars and confectionery & 34.4 & 17.2 \\
Beverages and tobacco & 70.8 & 52.5 \\
Cotton & 12.0 & 7.0 \\
Other agricultural products & 21.7 & 6.7 \\
Fish and fish products & 29.8 & 10.6 \\
Minerals and metals & 7.5 & 12.4 \\
Petroleum & 3.8 & 10.7 \\
Chemicals & 7.9 & 9.6 \\
Wood, paper, etc. & 9.1 & 15.5 \\
Textiles & 14.7 & 16.7 \\
Clothing & 13.4 & 24.8 \\
Leather, footwear, etc. & 10.2 & 14.9 \\
Nonelectrical machinery & 7.3 & 9.3 \\
Electrical machinery & 7.2 & 14.7 \\
Transport equipment & 20.7 & 24.7 \\
Manufactures, n.e.s. & 8.9 & 13.1 \\
\hline
\end{tabular}

* For latest year for which information is available.

Source: World Trade Organization, country tariff profiles.

Table 8: Distribution of effective ad valorem tariffs on textiles in India

\begin{tabular}{lcc}
\hline Range $(\%)$ & Rate $(\%)$ & Percentage \\
\hline 0 to 10 & 35 & 15.7 \\
Above 10 to 25 & 83 & 37.2 \\
Above 25 to 50 & 61 & 27.4 \\
Above 50 to 100 & 31 & 13.9 \\
Above 100 & 13 & 5.8 \\
& 223 & 100.0 \\
\hline
\end{tabular}

Source: Authors' estimates. 
India also operates an elaborate subsidy regime in agriculture. Subsidies on agricultural inputs such as fertilizer, power, water, tractors, and seeds, etc., exceed 5 percent of GDP (Institute of Public Policy, 2012). The corresponding magnitude for Pakistan is 1 percent of GDP. It must, of course, be recognized that the agricultural subsidies are WTO-compliant, but their high level in India has served to make domestic production artificially competitive in relation to imports.

Overall, India's tariff and subsidy regimes for agricultural products and tariffs on textiles and clothing have effectively restricted imports. For Pakistan, the consequence has been limited access of its traditional exports to the Indian market. It is worth noting that these two product groups also feature prominently in SAFTA's sensitive list. As such, the process of trade liberalization is unlikely to provide a significant new opening to Pakistani exporters.

As a special concession, India has recently offered Bangladesh dutyfree access to a range of textile products, including readymade garments. This is presumably justified on the grounds that Bangladesh is a leastdeveloped country member and merits special treatment. However, in the negotiations prior to granting India MFN status, Pakistan should seek the withdrawal of the specific duties on textiles and clothing and application only of the ad valorem duties.

\section{Nontariff Barriers}

The perception in Pakistan is that India operates a generally restrictive trade regime in the form of a wide range of NTBs, some of which are applied more strictly on Pakistani consignments. The following sections list the two countries' NTBs.

\subsection{NTBs in India}

According to the WTO (2011), India operates the following key NTBs.

- Sanitary and phytosanitary (SPS) measures are harmonized with international standards and cover mostly food items.

- The import licensing and permit regimes are complex, varying according to product or user. 
- There are a large number of notifications specifying mainly sampling and testing procedures as well as labeling and packaging requirements for food products, pharmaceuticals, textiles, etc.

- Quarantine is imposed on animals and plants.

- Some goods can only be imported through specified ports and/or by particular agencies.

- Pre-shipment inspection is mandatory for some goods such as metal scrap, textiles, etc.

- India actively uses antidumping duties and countervailing measures.

\subsection{NTBs in Pakistan}

Compared to those listed above, Pakistan operates fewer, less rigorous NTBs, listed below.

- Pakistan's main trade policy instrument is the tariff regime (including SROs) rather than NTBs.

- Pakistan's SPS legislation is outdated and not effectively applied.

- Imports of products such as pharmaceuticals, agricultural products, and engineering goods require clearance by the relevant ministry/agency.

- Import restrictions are applied for health, safety, security, religious, and environmental reasons.

- State trading agencies (such as the TCP) play a dominant role in the import of agricultural inputs and products.

- Pakistan seldom resorts to antidumping and countervailing measures.

The World Bank (2012) has developed an overall trade restrictiveness index (OTRI), which calculates the equivalent uniform tariff of a country's tariff schedule and NTBs that would maintain the overall import level. NTBs covered by the index include price control measures, quantity restrictions, monopolistic practices, SPS and technical regulations, and agricultural support.

Table 9 presents the OTRI for a sample of Asian countries. India has the highest OTRI, not only among countries in South Asia but also in relation to the sample of countries in the rest of Asia. The impact of NTBs on the magnitude of the OTRI also appears to be relatively high in India's 
case. A comparison with Pakistan reveals clearly that NTBs play a far less dominant role than in India. This point needs to be stressed in ongoing negotiations with India.

Table 9: OTRI in a sample of Asian countries

\begin{tabular}{lcc}
\hline Country & OTRI & $\begin{array}{c}\text { Percentage increase in } \\
\text { OTRI due to NTBs }\end{array}$ \\
\hline South Asia & & \\
Bangladesh & 23.8 & 0.8 \\
India & 46.7 & 24.5 \\
Nepal & 16.1 & 0.0 \\
Pakistan & 22.2 & 5.1 \\
Sri Lanka & 9.9 & 0.0 \\
East Asia & & \\
China & 21.2 & 9.9 \\
Malaysia & 39.7 & 30.0 \\
Philippines & 34.5 & 30.5 \\
Thailand & 22.8 & 8.1 \\
Rest of Asia & & \\
Turkey & 15.1 & 2.7 \\
\hline
\end{tabular}

Source: World Bank (2012).

Specific impediments to trade between India and Pakistan include the following.

1. Severe visa restrictions by both countries make it difficult for businesspersons from one country to develop contacts/markets in the other.

2. Restrictions on the choice of routes that can be used to transport goods constrain trade. For example, Pakistan limits the use of the Atari-Wagah border overland route to 137 goods from India.

3. There is limited capacity for transport on overland routes, especially the availability of wagons from Pakistan Railway. In addition, there are no testing or quarantine facilities at the check-post at AtariWagah. There is no e-filing system in operation at the border customs, leading to significant delays, frequently for security reasons.

4. In some cases, the testing and certification required under SPS measures and technical barriers to trade take considerable time in India. 
5. Banking channels remain underdeveloped in the absence of bank branches in one country of banks in the other. This has created problems in honoring letters of credit. Payments through the Asian Clearing Union are also subject to long delays.

These impediments appear to have had a major impact on the volume of trade between the two countries. Fortunately, some steps have recently been taken to improve the situation. The countries have reached a bilateral agreement to expedite customs clearance on accepting each other's certification of goods. There are ongoing discussions on a visa protocol to facilitate longer, more frequent by businesspersons. Overall, it is clear that NTBs are generally more restrictive in India, especially on agricultural items. There are also a number of specific impediments to bilateral trade, which, if removed, could significantly enhance the volume of trade.

\section{Prospects for Indo-Pakistan Trade}

We have demonstrated above that granting MFN status to India, rationalizing tariffs on Pakistani products by India, and mutual efforts to remove specific impediments to trade could substantially enhance the volume of trade between the two countries. A number of other studies have already reached this conclusion, including those by Batra (2004), Nabi and Nasim (2001), the State Bank of Pakistan (2006), Sayeed (2005), Kemal, Abbas, and Qadir (2002), Hussain (2011), and Taneja (2007). Such studies have adopted different approaches to demonstrate that the potential volume of trade could be a multiple of its present level.

Following the granting of MFN status, there is considerable scope for the diversion of imports by Pakistan to India, especially in product groups such as chemicals, pharmaceuticals, iron and steel, electrical appliances, plant and machinery, motor vehicles, and transport equipment. The gains to Pakistan would be in the form of lower prices (especially due to India's proximity and the resulting lower transport costs). The State Bank of Pakistan (2006) estimates that the diversion of trade to India could confer savings in the import bill of over USD 1 billion.

There is also the likelihood of some "trade creation" following the implementation of SAFTA, especially in items that are currently not imported but could witness the entry of Indian products as the result of a sizeable fall in the rate of customs duty from 20-30 percent to 5 percent. In addition, informal imports through various channels from India could shift to official imports. Overall, in the medium term, it is estimated that imports 
from India could rise to almost USD 7 billion to 8 billion, especially if there is significant trade creation. This would more-than-quadruple the present level of imports. If this happens, India could become one of Pakistan's largest trading partners in Asia, along with China and the Middle East countries.

On the export side for Pakistan, the prospects appear somewhat more limited. The outcome depends on the extent to which India eases both general and Pakistan-specific barriers to trade, and rationalizes tariffs, especially on textiles. The reduction of duties under SAFTA may not be of great benefit because its sensitive list protects agriculture and textiles. Indian duties on manufactured goods, except textiles and clothing, are relatively low and, consequently, the extent of tariff reduction under SAFTA will not be so pronounced. Overall, Pakistan would do well if it were able to increase its exports to India to USD 1 billion from the present level of about USD 350 million in the next few years. This would nearly treble its exports to India.

It needs to be emphasized that there are threats to realizing this quantum jump in bilateral trade. First, industries in Pakistan that have traditionally enjoyed high levels of effective protection will lobby for the negative list, including their products, to be retained beyond 31 ${ }^{\text {st }}$ December 2012 on the grounds that they fear "serious injury" due to the opening of trade following full trade normalization with India. While Pakistan adheres to its commitment to grant MFN status, it may be necessary to enhance the institutional capacity of the Ministry of Commerce and National Tariff Commission to investigate complaints of serious injury and take appropriate safeguard measures, if necessary, permissible under the WTO and SAFTA.

Second, there are likely to be elements in India who are opposed to granting any concessions to Pakistan in negotiations on the future bilateral trading regime. This may include not only right-wing political forces, but also, potentially, certain industries such as textiles and clothing.

Third, the prospects of an increase in Pakistan's trade deficit with respect to India will fuel arguments on the part of right-wing elements and industrial lobbies in the country that the process of liberalization has been to India's advantage and that Pakistan has lost the major leverage it had with regard to resolution of the longstanding Kashmir problem. It will be necessary to convey the message that, while the trade deficit with respect to India may worsen, the global balance of trade will simultaneously improve 
due to cheaper imports from India. A powerful way of establishing this point may be to demonstrate the large consumer welfare gains that could accrue in a range of products, including certain basic food items, medicines, personal care items, electrical goods, and transport equipment (especially for public transport).

Finally, the recent improvement in the trading environment between the two countries can only be sustained if both pursue a policy of reciprocity and mutual cooperation, and if political relations are not strained and security concerns not heightened. It is possible that the expansion of trade between the two countries will facilitates the process of composite dialogue and confer a large peace dividend in the not-so-distant future. 


\section{References}

Batra, A. (2004). India's global trade potential: The gravity model approach (Working Paper No. 151). New Delhi, India: Indian Council for Research and International Economic Relations.

Hussain, I. (2011). Prospects and challenges for increasing India-Pakistan trade. Washington, DC: Atlantic Council.

India, Ministry of Commerce and Industry. (2012). Export import data bank. Retrieved from http:/ /commerce.nic.in/eidb/default.asp.

Institute of Public Policy. (2012). Non-tariff barriers of India and Pakistan and their impact. Lahore, Pakistan: Author.

Kemal, A. R., Abbas, M. K., \& Qadir, U. (2002). A plan to strengthen regional trade and cooperation in South Asia. In T. N. Srinivasan (Ed.) Trade, finance and investment in South Asia. New Delhi, India: Social Science Press.

Nabi, I., \& Nasim, A. (2001). Trading with the enemy: A case for liberalizing India-Pakistan trade. In S. Lahiri (Ed.), Regionalism and globalization: Theory and practice. London, UK: Routledge.

Pakistan, Ministry of Commerce. (2012). Customs tariffs. Islamabad, Pakistan: Author.

Sayeed, A. (2005). Gains from trade and structural impediments to India-Pakistan trade. Karachi, Pakistan: Collective for Social Science Research.

State Bank of Pakistan. (2006). Implications of liberalizing trade and investment with India. Karachi, Pakistan: Author.

State Bank of Pakistan. (2011). Exports and imports of goods and services Annual. Karachi, Pakistan: Author.

Sustainable Development Policy Institute. (2007). Quantifying informal trade between Pakistan and India. Islamabad, Pakistan: Author.

Taneja, N. (2007). Pakistan-India trade: View from the Indian side. In Z. Naqvi \& P. Schuler (Eds.), The challenges and potential for PakistanIndia trade. Washington, DC: World Bank. 
World Bank. (2012). World trade indicators 2009/10: Trade policy. Retrieved from http:/ /info.worldbank.org/etools/wti/3a.asp.

World Trade Organization. (2008). Trade policy review: Pakistan. Retrieved from http:/ / www.wto.org/english/tratop_e/tpr_e/tp_rep_e.htm.

World Trade Organization. (2011). Trade policy review: India. Retrieved from http://www.wto.org/english/tratop_e/tpr_e/tp_rep_e.htm. 